\title{
THE PERCEPTION OF THE EUROPEAN UNION BY THE FARMERS OF LUBELSKIE VOIVODESHIP: THE RESULTS OF SURVEY-BASED RESEARCH
}

\author{
Hubert Maj ${ }^{1}$
}

Received 2 September 2008; Accepted 9 March 2009

\begin{abstract}
The paper presents the results of questionnaire surveys, which were conducted among farmers. Surveys were conducted from May to August 2007 in the eastern part of Poland, in Lubelskie voivodeship. This is the voivodeship, where an agriculture plays significant role in comparison with other regions of the country. Additionally, the lowest support to integration with European Union was noticed in the public referendum. However, according to the questionnaire surveys, the farmers gave bigger support for ratification the Treaty. The results of research answers the question how farmers in Lubelskie voivodeship perceive the European Union 3 years after the access. In addition, we could indicate, which factors cause increase and which one cause decrease in the support for the European Union.
\end{abstract}

Key words: survey-based research, perception, the European Union, Poland, Lubelskie voivodeship, farmers

Streszczenie: Artykuł prezentuje wyniki badań ankietowych przeprowadzonych wśród użytkowników indywidualnych gospodarstw rolnych w okresie maj - sierpień 2007 r. Badania przeprowadzono we wschodniej części Polski, w województwie lubelskim. Jest to region, w którym rolnictwo odgrywa szczególna rolę w porównaniu $z$ innymi obszarami kraju. Jednocześnie zanotowano tu najniższe poparcie dla integracji z Unią Europejska, wyrażone w referendum przedakcesyjnym. Jednak, według badań ankietowych, rolnicy udzielili o wiele szerszego poparcia dla ratyfikacji Traktatu. Wyniki badań dają odpowiedź na pytanie jak rolnicy województwa lubelskiego postrzegają Unię Europejską 3 lata po akcesji. Pozwalają również na określenie stymulantów i destymulantów tego poparcia.

Słowa kluczowe: badania ankietowe, spostrzeganie, Unia Europejska, Polska, wojewódzstwo Lubelskie, chłopi

\section{Introduction}

Following the national referendum, Poland approved the Treaty concerning its entry into the European Union and became its member on $1^{\text {st }}$ May 2004. The accession enforced a number of social and economic changes. The consequences of the changes were especially noticeable in the case of agriculture. The accession brought along a lot opportunities as well as threats for

\footnotetext{
1 M.Sc. Hubert Maj, Economic Geography Unit, Institute of Earth Sciences, Maria Curie-Skłodowska University, Krasnicka 2, Lublin, Poland, e-mail: hubertmaj@wp.pl
} 
the users of individual agricultural households. On the one hand, since the accession, farmers have been able to apply for subsidies from the structural funds and sell their produce to all the countries of the European Union and to those associated with the EU. On the other hand, Polish farmers fear that they may not face the competition imposed by the farmers of the "old" Union. Agricultural households in Western Europe have a more favourable agrarian structure. Besides, they have always received and still obtain higher subsidies than Polish agriculture. Some Polish farmers have attempted to modernize their households and they hold positive opinions on their functioning in the European Union. Others consider the European Community as a source of their own failures.

Lubelskie voivodeship is an area of Poland, where agriculture is of primary importance. Consequently, the voivodeship was chosen as the area for survey research. It concerned the farmers' perception of the European Union. The aim of the research was to determine how agricultural households function after Poland's entry into the European Union. The issue concerning the perception of the European Union is directly connected with it.

\section{Research area}

Lubelskie voivodeship is situated in the Eastern part of Poland (fig. 1). It is the third largest voivodeship in Poland, following Mazowieckie (Masovian) and Wielkopolskie (Great Poland). Its area is $25122 \mathrm{~km}^{2}$ and number of inhabitants: 2166210 . Agriculture is one of the most important sectors of its economy. That is reflected in the following facts. Lubelskie has the greatest share of the population employed in agriculture in relation to the total of all the employed $(35.8 \%$ in 2006).

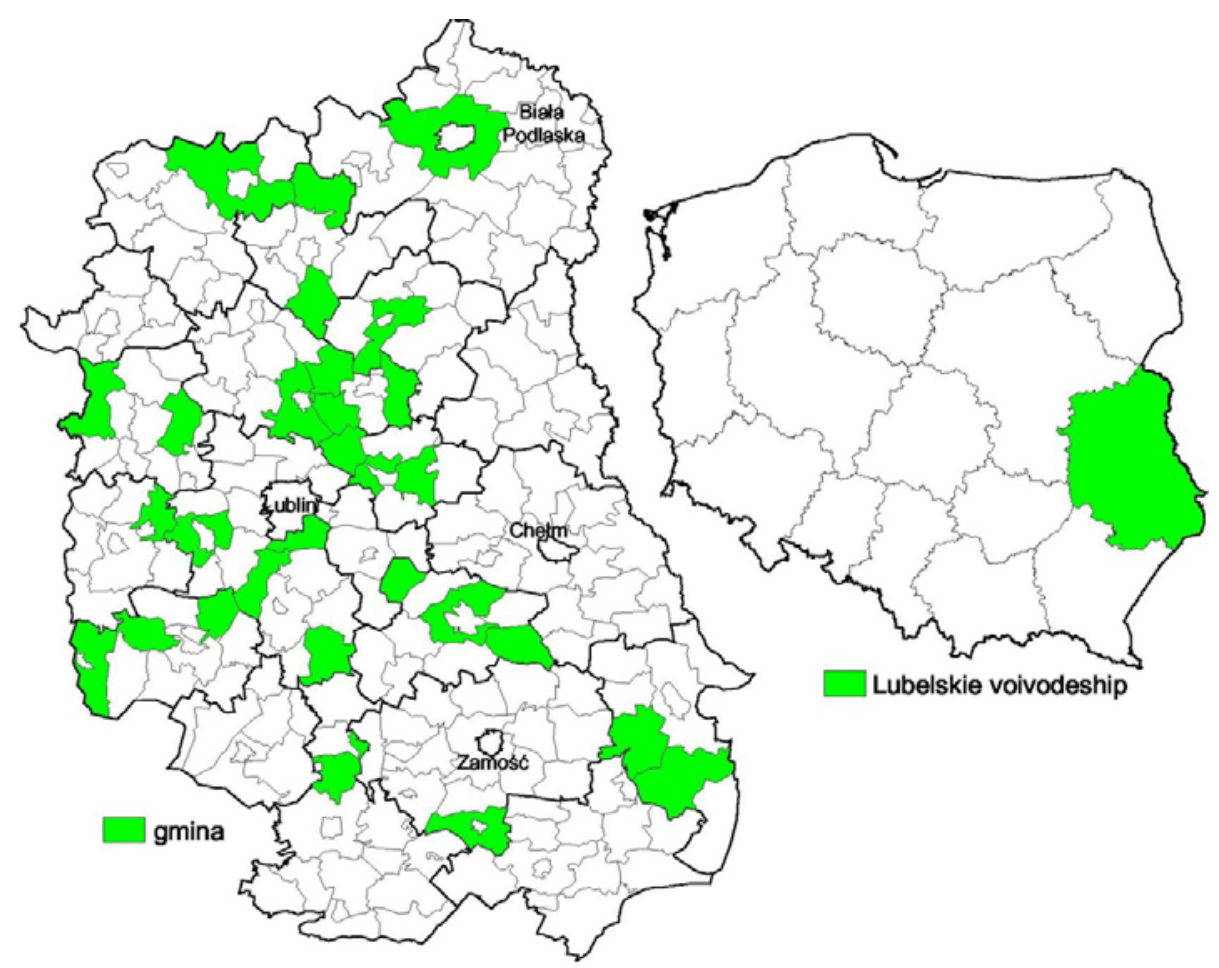

Fig 1. Research area

Source: own elaboration.

Following Mazowieckie, it also has the largest number of households with agriculture as the main source of income. The percentage of agricultural land in the structure of land use is $68.1 \%$. Other characteristics of research area are shown in table 1. Lubelskie's advantageous natural conditions favour its agricultural production. However, despite all this, the position of Lubelskie's agriculture is still a problematic issue. Therefore, "the priority of the development of Lubelskie voivodeship is the restructuring of agriculture and multi-functional development of rural areas" (Strategia...2005, p. 20). 


\begin{tabular}{|c|c|c|c|}
\hline FEATURE & VALUE & UNIT & YEAR \\
\hline rural population & 53.4 & $\%$ & 2007 \\
\hline population density & 86.2 & population/area & 2007 \\
\hline physiological population density & 127.4 & population/agricultural lands & 2005 \\
\hline urbanization rate & 46.6 & $\%$ & 2007 \\
\hline average farm area & 6.0 & ha & 2005 \\
\hline feminization rate & 103.1 & number women/100 men & 2007 \\
\hline feminization rate on rural areas & 100.9 & number women/100 men & 2007 \\
\hline feminization rate among population in age $20-29$ & 96.9 & number women/100 men & 2007 \\
\hline feminization rate on rural areas among population in age $20-29$ & 94.8 & number women/100 men & 2007 \\
\hline population in economically before-productive age & 25.3 & $\%$ & 2002 \\
\hline population in economically productive age & 56.1 & $\%$ & 2002 \\
\hline population in economically post-productive age & 18.6 & $\%$ & 2002 \\
\hline birth rate & -0.7 & $\%$ & 2007 \\
\hline migration balance & -2.2 & $\%$ & 2007 \\
\hline percentage of population with higher education & 9.4 & $\%$ & 2002 \\
\hline percentage of population with agricultural education & 14.0 & $\%$ & 2002 \\
\hline percentage of arable lands in total agricultural lands & 79.4 & $\%$ & 2002 \\
\hline percentage of meadows and pastures in total agricultural lands & 17.7 & $\%$ & 2002 \\
\hline percentage of orchards in total agricultural lands & 2.9 & $\%$ & 2002 \\
\hline percentage of uncultivated lands in total arable lands & 12.4 & $\%$ & 2002 \\
\hline percentage of wheat in total sown area & 25.8 & $\%$ & 2002 \\
\hline percentage of cereal mixed in total sown area & 13.4 & $\%$ & 2002 \\
\hline percentage of rye in total sown area & 11.0 & $\%$ & 2002 \\
\hline percentage of barley in total sown area & 10.8 & $\%$ & 2002 \\
\hline percentage of potatoes in total sown area & 7.4 & $\%$ & 2002 \\
\hline percentage of oats in total sown area & 7.2 & $\%$ & 2002 \\
\hline cattle stock per 100 hectares of agricultural lands & 28.9 & number/100 ha & 2002 \\
\hline pigs stock per 100 hectares of agricultural lands & 88.1 & number/100 ha & 2002 \\
\hline horses stock per 100 hectares of agricultural lands & 2.9 & number/100 ha & 2002 \\
\hline sheep stock per 100 hectares of agricultural lands & 1.7 & number/100 ha & 2002 \\
\hline hens stock per 100 hectares of agricultural lands & 649.3 & number/100 ha & 2002 \\
\hline average area of gmina on rural areas & 12,517 & ha & 2007 \\
\hline average number of people in gmina on rural areas & 6,068 & number & 2002 \\
\hline average number of inhabitants in household & 3.14 & inhabitants/number of households & 2007 \\
\hline
\end{tabular}

Tab 1. Characteristic of research area

Source: own calculations based on dates of Central Statistical Office (GUS).

The restructuring of agriculture in Lubelskie voivodeship is facilitated by the integration with the European Union. Poland ratified the Treaty concerning its entry into the European Union thanks to the support gained at the national referendum. The referendum was conducted on June 2003. There was only one question: "Do you agree with joining Poland to the European Union?" According to the State Election Commission (PKW - Państwowa Komisja Wyborcza), the referendum turnout was $58.9 \%$ of those entitled to vote. In Lubelskie voivodeship the turnout was lower than average $(55.5 \%)$. The support for the ratification of the Treaty was also the lowest in Lubelskie (63.3\% of votes). The survey-based research conducted among the farmers of Lubelskie voivodeship shows slightly different results.

\section{Survey research}

The survey questionnaires concerned the issues connected with the functioning of the agricultural household, its changes and development perspectives. The analysis also comprised the social profile of individual users of the agricultural household and their opinions on the issues concerning agriculture. Most were close-ended questions, which enabled the researcher to obtain answers that were more precise. Before the proper research was conducted, trial tests were carried out twice. They were aimed at eliminating mistakenly formulated questions. The work on the questionnaire text consists in the introduction of subsequent corrections, each of which should bring us closer to the final version of the survey (Mangione 1999).

The survey was conducted among a group of individual users of agricultural households in Lubelskie voivodeship. The notion of the "user" is understood as the owner or leaseholder of the 
agricultural household. "Cooperative agriculture" was omitted deliberately in the paper. It does not play a major role in the voivodeship. The share of the area of individual agricultural households in the general acreage of agriculture land is $95.4 \%$ (2005). The survey was conducted only among the users of agricultural households of over 1 ha. Smaller land areas are treated as agricultural lots. Detailed characterization of respondents and their households is presented in table 2.

\begin{tabular}{|c|c|c|c|}
\hline FEATURE & CHARACTERISTIC & VALUE & UNIT \\
\hline gender structure & percentage of males & 73.4 & $\%$ \\
\hline \multirow{3}{*}{ struktura wieku } & mobile age (18-44) & 40.0 & $\%$ \\
\hline & no-mobile economically productive age $(45-59 / 64)$ & 51.9 & $\%$ \\
\hline & economically post-productive age (above 59/64) & 8.1 & $\%$ \\
\hline \multirow{4}{*}{ marital status } & married & 82.9 & $\%$ \\
\hline & bachelor/spinster & 9.8 & $\%$ \\
\hline & Widowem/widow & 6.7 & $\%$ \\
\hline & divorcee & 0.6 & $\%$ \\
\hline kind of education & agricultural education & 37.8 & $\%$ \\
\hline \multirow{6}{*}{ poziom wykształcenia } & without education & 0.5 & $\%$ \\
\hline & primary education & 11.4 & $\%$ \\
\hline & vocational secondary education & 38.0 & $\%$ \\
\hline & secondary education & 35.1 & $\%$ \\
\hline & post-secondary education & 4.5 & $\%$ \\
\hline & high er education & 10.4 & $\%$ \\
\hline size of household & average number of inhabitants in household & 4.3 & number \\
\hline \multirow{4}{*}{ sources of households' income } & only agriculture & 27.2 & $\%$ \\
\hline & mainly agriculture & 14.1 & $\%$ \\
\hline & agriculture and other activities & 40.5 & $\%$ \\
\hline & mainly other activities & 18.2 & $\%$ \\
\hline income of the head of household & only agriculture & 40.3 & $\%$ \\
\hline farm area & average farn area & 8.0 & ha \\
\hline \multirow{6}{*}{ structure of farm areas } & $1-5$ ha & 14.7 & $\%$ \\
\hline & $5-10$ ha & 27.2 & $\%$ \\
\hline & $10-20$ ha & 29.6 & $\%$ \\
\hline & $20-30$ ha & 10.8 & $\%$ \\
\hline & $30-50$ ha & 10.5 & $\%$ \\
\hline & above 50 ha & 7.2 & $\%$ \\
\hline agrarian structure & average plots' number & 5.5 & number \\
\hline \multirow{3}{*}{ structure of agricultural land use } & arable lands & 82.9 & $\%$ \\
\hline & orchards & 5.8 & $\%$ \\
\hline & meadows and pastures & 11.3 & $\%$ \\
\hline animal production & percentage of farmers who maintain animals & 62.9 & $\%$ \\
\hline mechanisation & percentage of traktor owners & 79.0 & $\%$ \\
\hline market production & percentage of farmers selling their agricultural & 84.0 & $\%$ \\
\hline
\end{tabular}

Tab 2. Characteristic of respondents

Source: own elaboration.

The survey analysis comprised the period of May - August 2007. From 1,504 questionnaires, 1,361 were selected for further analysis $(90.5 \%$ of the total). The incorrectly completed ones were omitted. The mistakes resulted either from the carelessness of the surveyors or the very respondents. Despite this, the number of questionnaires is adequate. Research of random sample size revealed that for population of farmers from the voivodeship, even trial of 1,024 respondents could be representative. The survey was carried out in selected gminas (communes) of Lubelskie voivodeship. The criterion for such a selection was the typology of rural areas according to Bański and Stola (Bański, Stola 2002). The spatial distribution of research gminas is presented in figure 1.29 gminas were selected from 172 rural gminas of Lubelskie voivodeship. Their spatial distribution is large. The selected gminas are situated in 14 out of 20 districts of Lubelskie voivodeship. 


\subsection{The support for the integration with the European Union}

The research survey showed that farmers, in comparison to the rest of the society, were more interested in the participation in the referendum concerning Poland's entry into the European Union. From among the respondents who answered the question "Did you take part in the referendum concerning Poland's entry into the EU?", $72.5 \%$ answered "yes". It is a result $17 \%$ higher than the official data for the voivodeship. The support for the accession of Poland was given by $85.5 \%$ of the surveyed farmers who had participated in the referendum. In comparison to the results of the State Election Commission (PKW), among farmers there were $22.3 \%$ more supporters of the European Union. It is not consistent with the pre-referendum opinion, common in certain circles, according to which farmers were not expected to give widespread support to the integration with the European Union. It was considered that they feared the competition of the better-developed agriculture of Western Europe.

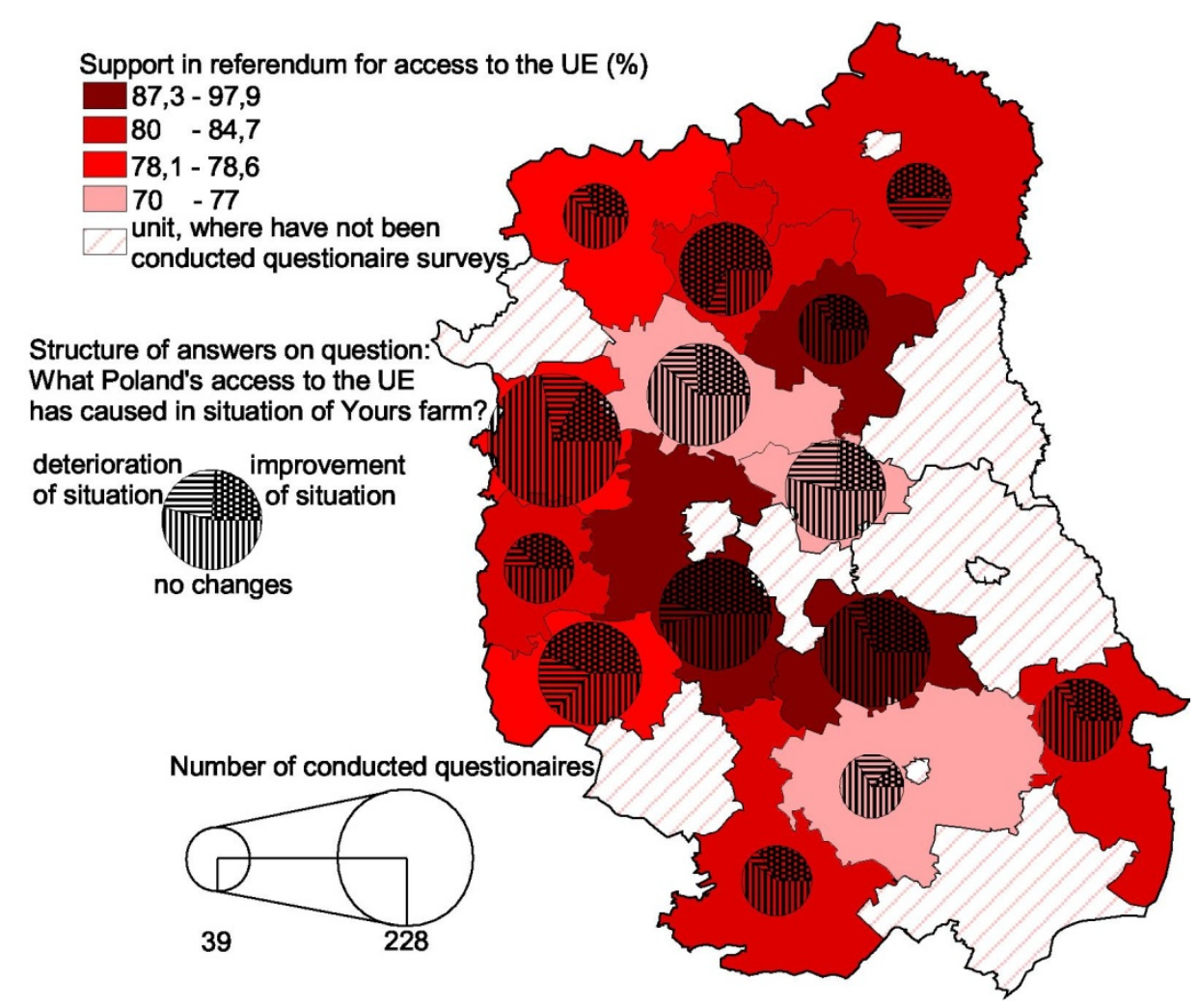

Fig 2. Support and perception of the EU

Source: own elaboration.

The analysis proved that there exist significant differences as to the level of support within Lubelskie voivodeship (fig. 2). Among the respondents in the analysed administrative units, the referendum support for the accession Treaty was from $70.0 \%$ in Zamojski district in the south of the voivodeship to $97.9 \%$ in Parczewski district in the northern part of the voivodeship. However, this cannot be defined as the regionalization of the support for the accession to the European Union. Similar in terms of value support indices are distributed unevenly and they do not constitute homogenous groups. Also, according to the official State Elections Commission (PKW), the support for the European Union is distributed unevenly.

At present, the farmers' support for the European Union has slightly decreased. The questionnaire asked "Would you hypothetically support the ratification of the Treaty if the referendum was held again?" $82.9 \%$ respondents would again agree to approve the accession of Poland to the EU. The result is lower by $2.6 \%$ than in 2003 . One positive aspect is that from among those voting against Poland's accession to the EU, at present $31.6 \%$ would hold the opposite opinion. However, this is a smaller group. Hence, the rise in support even by $1 / 3$ does not mean a higher increase in support among the total number of the respondents. 


\subsection{The accession to the European Union versus the development of agricultural households}

Currently, the farmers' perception of the European Union mainly depends on the economic condition of their households in the post-accession period. The assessment of the situation from the point of view of the individual users of agricultural households is reflected in the answers to the questionnaire question:

\section{"What Poland's access to the EU has caused in situation of Yours household:

$\uparrow$ improvement $\quad \uparrow$ deterioration changes?"

Structure of the answers on this question was acknowledged as a dependent variable. Her factorization is expressed by few independent variables. There are: taking part in the referendum and voting for the integration, age of respondents, their assessment of situation in Polish agriculture, farm area, marketability of production, changes in farms after the accession and hypothetical changes in the nearest future. All of them relate to the assessment of changes in households, which were initiated by a membership of Poland in the European Union. Farmers perceive the Union mainly by their own successes and failures.

Three years after the accession, most respondents did not notice any changes in their households as caused by Poland's entry to the European Union (fig. 3). This is consistent with the survey research conducted right after the accession referendum. The farmers were then asked to estimate the chances of the development of their households after the accession (Bański, Czapiewski 2003). In the pre-accession period a large group of farmers, $40 \%$, did not have any opinion as for the future of their households after Poland's entry into the European Union (Bański 2004). Many respondents, however, believe that only the largest agricultural households, few of which are found in the voivodeship, have a possibility to undergo significant changes and develop in the conditions of the EU integration. Only $1 / 3$ of the interviewed farmers see the improvement in the condition of their households.

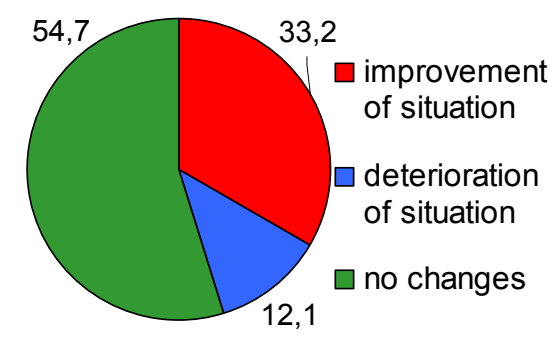

Fig 3. Structure of answers on question: "What Poland's access to the EU has caused in situation of Yours farm?”

Source: own elaboration.

The spatial distribution of the response structure to the above question is presented in the diagram in figure 2. A positive estimate of the situation is characteristic of the households situated in the northern part of the voivodeship (Bialski and Radzyński districts), which is connected with a more favourable agrarian structure in this area. Also, in the gminas located in Lubelski district there can be observed a certain increase in the answers confirming an improvement in the household situation and a decrease in the answers showing that their situation worsened. It is conditioned by a different demographic and economic profile of the users of agricultural households. In the rural areas located within the near distance to Lublin, the users of agricultural households are young people who are better educated and have higher incomes obtained from their work in the voivodeship city.

As results from the survey, a lot of farmers are not familiar with the types of financial subsidies offered by the European Union. They know very little about them and actually the only form of subsidies they are aware of is the direct ones, as $85,4 \%$ of the surveyed declared. Only a few percent of the farmers declare that they are familiar with the remaining EU funds. The situation in terms of using those funds looks even worse yet. Direct subsidies are used by $78 \%$ of the surveyed, whereas the remaining forms of support are of interest to a relatively small number of the respondents. 


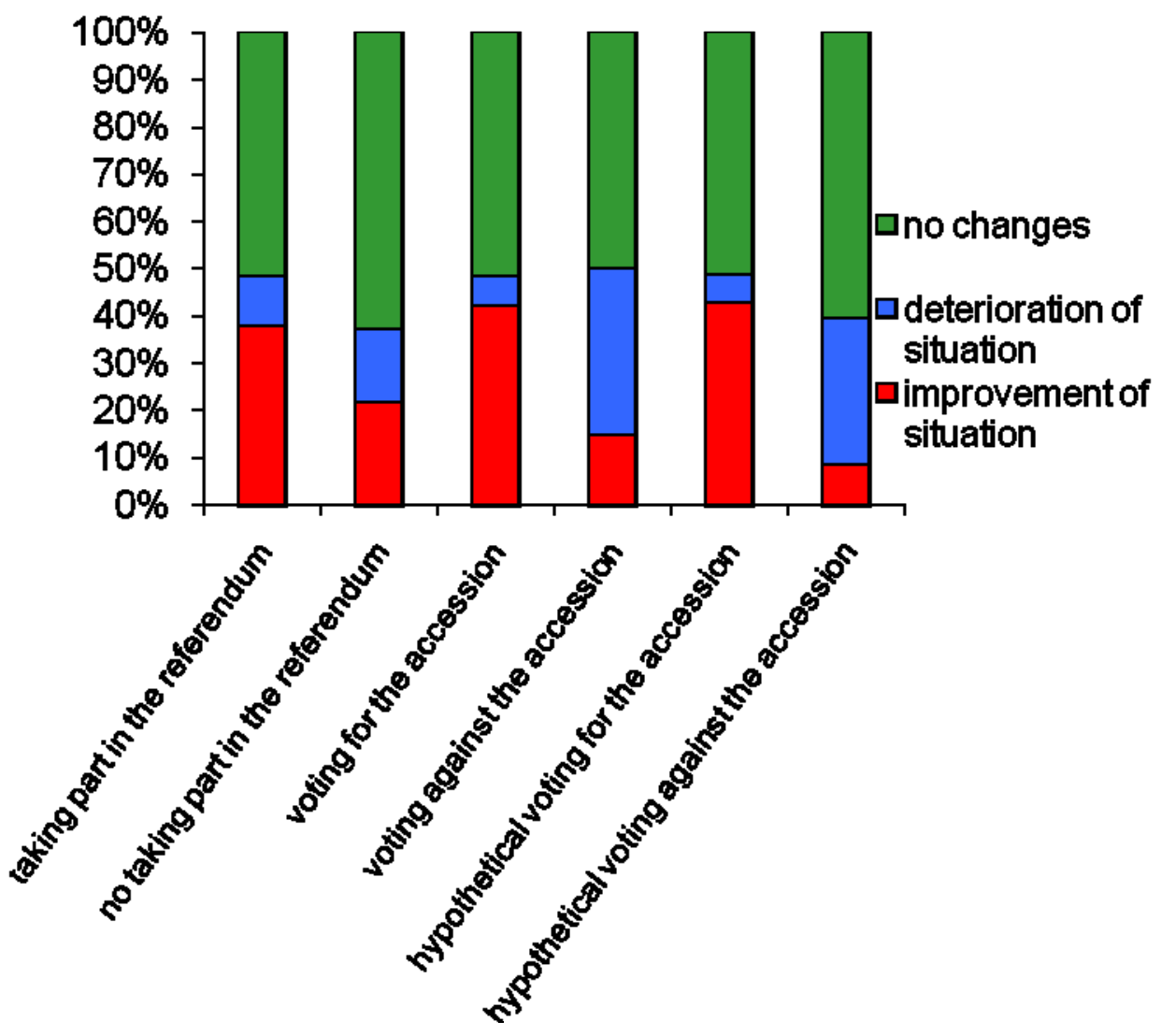

Fig 4. An assessment of situation in farm, depending on taking part in the referendum, voting and hypothetical voting in the referendum

Source: own elaboration.

There are close relationships between the assessment of changes in the agricultural household caused by the accession to the European Union, the participation in the referendum and declared support for the Treaty approval (fig. 4). It is particularly noticeable in the case of people, who voted against the accession and who would vote in the same way if the referendum was held again. Those who claim that Poland's entry into the European Union worsened their situation constitute the largest number among those respondents. These are hardened Euroskeptics disappointed with the Community and who treated it with suspicion and distrust from the very beginning.
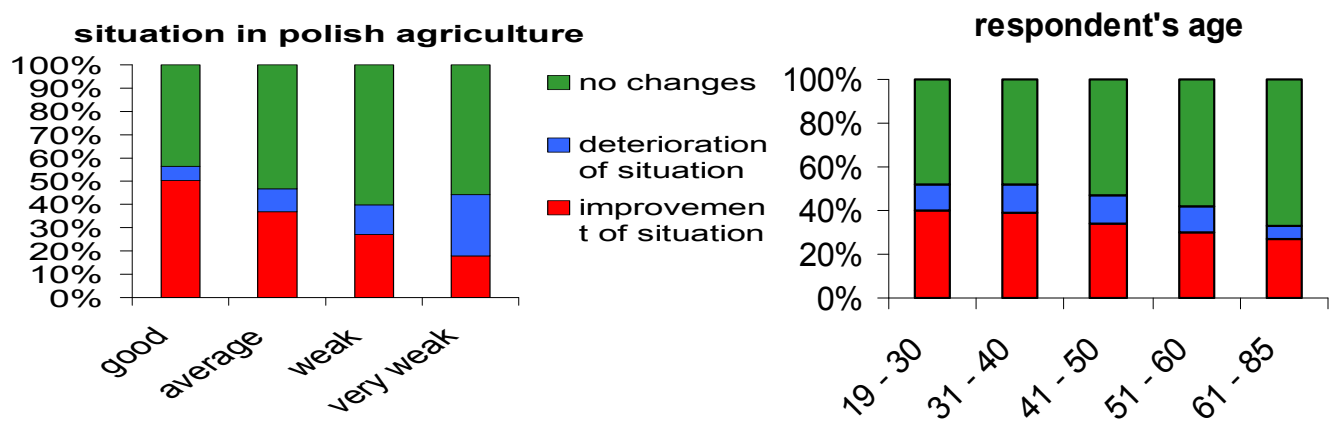

Fig 5. An assessment of situation in farm, depending on the assessment of situation in Polish agriculture and age of respondent

Source: own elaboration.

The perception of changes within the agricultural household after the accession of Poland to the EU correlates with the general assessment of the condition of Polish agriculture. The questionnaire comprised a question concerning this issue as well. On the basis of the research 
results, it can be concluded that farmers, who estimated the condition of Polish agriculture more favourably saw that the condition of their households improved respectively (fig. 5). Those are people, who succeeded in running their agricultural economic activity and who see an opportunity for themselves in the functioning of the Common Market. In order that the condition of Polish agriculture is improved, $7.6 \%$ of the interviewed believe that the subsidies should be equalized with those in other European countries or that Poland should withdraw from the EU. Many of the interviewed claim that Polish farmers are treated unfairly by the European Union, mainly because of lower subsidies. Both the positive opinion on the state of Polish agriculture and the development of a particular household are related to the general economic situation of the respondents and their age. Younger users of agricultural households are of a more positive opinion on the condition of their households. They have better entrepreneurial skills and more initiative in terms of taking on new challenges. What seems significant is the fact that it was only this group of people that could benefit from the EU aid program "Easy start for young farmers". The level of optimism decreases with age. Older farmers are not as flexible as for their ability to adapt to the new situation. Therefore, they use the EU subsidies to a lesser extent. They are more traditional and they fear any innovations.

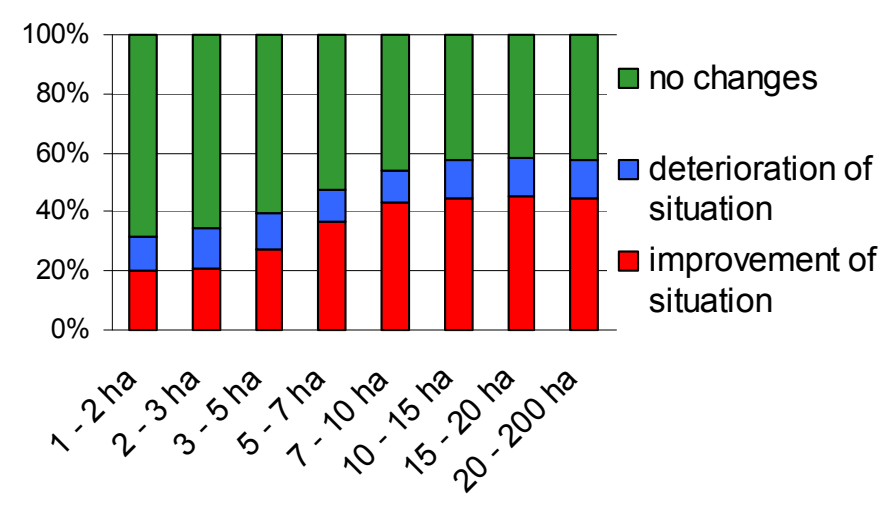

Fig 6. An assessment of situation in farm, depending on area of farm

Source: own elaboration.

A more positive assessment of the development of a particular household is directly proportional to the household acreage (fig. 6). The ratio of the respondents presenting more favourable opinions after the accession to the EU is twice as high among the users of the smallest households (up to $3 \mathrm{ha}$ ) as among those of medium-sized households (over $7 \mathrm{ha}$ ). The development possibilities of small households are very limited. It is difficult to obtain from them satisfactory income and considerable amount of production. Facing competition with the farmers of Western Europe is much easier for the users of larger households. Their satisfaction with Poland's entry into the European Union is closely related to larger direct subsidies they can obtain. The very farmers call them "area" or "acreage" subsidies, which proves that they are identified with the size of an agricultural household. Moreover, the owners of larger households have better possibilities of applying for other subsidies. Recently many of them used preferential bank loans to purchase machines or modernize their households, which was largely financed by the EU funds. Currently the cost of buying a new tractor is too high for the majority of farmers in Poland. Without the EU's aid it would be impossible to buy one.

There are also clear relationships between a positive assessment of changes in the agricultural household and the marketability of production. In Poland, small agricultural households dominate its central, eastern and southern parts. The production is run mainly for self-use. From among the respondents, as many as $15.9 \%$ do not sell agricultural produce at all. Another $13.3 \%$ sell less than a half of all of their whole produce. When these numbers are added, there arises a paradoxical situation. Almost $1 / 3$ of the farmers do not obtain income from their agricultural activity or it does not constitute a significant part of their income in total. But this is still better situation than average for the country. According to research of R. Kulikowski (2005), only $72.3 \%$ of polish farmers sell their produce. Moreover, $62.0 \%$ of them obtain less money that they spend for production costs. 
Barely $40.3 \%$ of the users of individual agricultural households declare that agriculture is the only source of income for them. In comparison to the whole country, there is more advantageous result. Just for $13.8 \%$ of members of agricultural families are maintained only or mainly by income from agriculture (Kulikowski 2005). As to the opinions of the respondents running their production for sale, there is mutual dependence: the higher the share of sales production, the higher the opinion on the changes in the agricultural household following the accession to the European Union (fig. 7). The share of respondents selling over $90 \%$ of their produce and at the same time favourably perceiving the changes in their households after Poland joining EU is twice as high as in the case of those selling less than a half of their produce. This variable clearly interprets the perception of the European Union by the farmers. Higher income obtained from the agriculture after the integration translates into more positive assessment of the European Union.
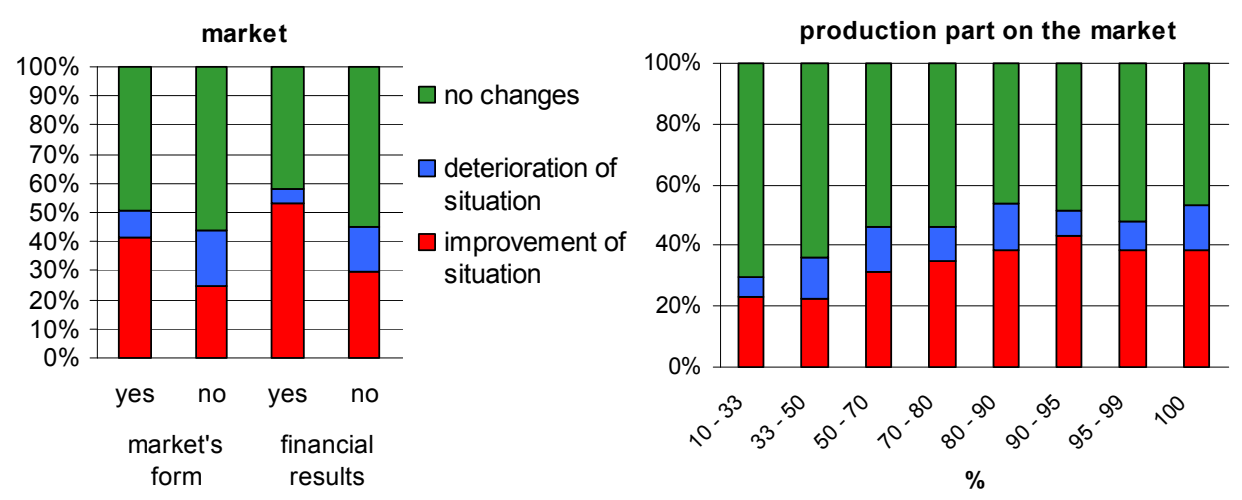

Fig 7. An assessment of situation in farm, depending on production part on the market, satisfaction with market form's and financial results

Source: own elaboration.

Poland's accession to the EU in a sense contributed to the price increase in agricultural goods. In turn, it influenced the economic situation of the farmers selling their produce. There is a clear relationship between the marketability of production and the perception of the European Union. Those satisfied with the form of selling their produce and with their prices hold positive opinions on changes within their own agricultural households. It is particularly noticeable in the case of the obtained financial results, which directly influence the functioning of agricultural households. Together with the increasing income from the conducted activity, one can observe a rise in the farmers' self-satisfaction and positive assessment of the household condition following the entry into the EU.

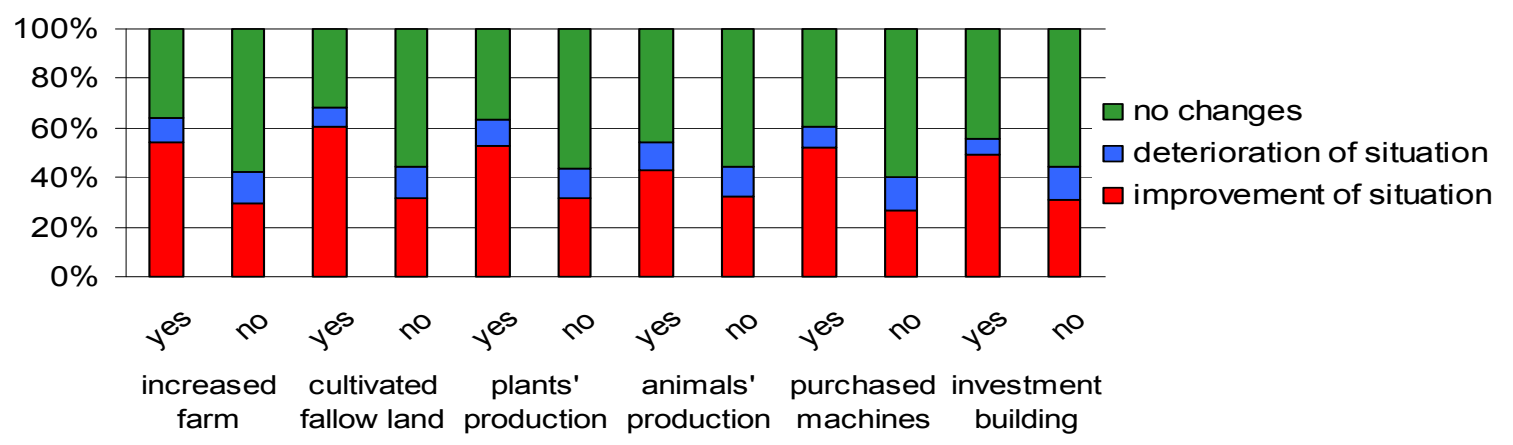

Fig 8. An assessment of situation in farm, depending on changes in farm in the years 2004-2007

Source: own elaboration.

Farmers seeking new ways of improving the economic condition of their households obtain higher income. Open to new challenges, they extend the area of cultivated land, make 
significant changes to the directions and the structure of production, and modernize agricultural households. Poland's entry into the European Union created better foundations for such activity. Farmers got the opportunity to apply for direct subsidies for the area of land they cultivate, subsidies for some of the EU-preferable directions of production (eg. subsidies within the agricultural-environmental program "Ecological Agriculture"), the possibility to apply for cheap bank loans or even co-finance their household investments by means of EU funds. The assessment of the situation within particular agricultural households after Poland's accession to the European Union in $2004-2007$ is shown in figure 8. It is presented in relation to whether any attempts to introduce significant changes were made or not. The respondents were asked whether they increased the acreage of their agricultural households, developed the previously uncultivated land, introduced significant changes to the plant or farm animal production, bought agricultural machines or realized construction investments. The users, who ran such activity are of a more favourable opinion on the changes following the EU Treaty approval.

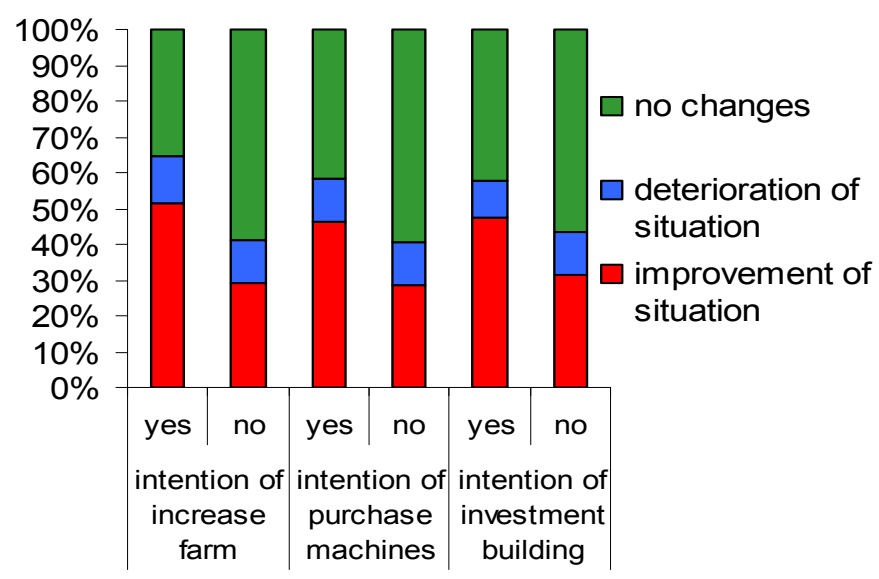

Fig 9. An assessment of situation in farm, depending on intensions of changes in farm in the nearest few years

Source: own elaboration.

Respectively, the same applies to farmers' future plans. Here clear differences concerning the assessment of the changes within the household condition in the post-accession period are noticeable in the case of an intention to enlarge a household, buy machines and introduce construction investments. In the same way, as in the case of the changes introduced recently, the respondents intending to introduce changes in the future assess the condition of their households more positively after Poland's entry into the EU (fig. 9). This is a group, which already obtains profits from Poland's accession to the European Union and intends to take steps aimed at further improvement in the economic condition of their households.

\section{Summary and conclusion}

The perception of the European Union by the farmers in Lubelskie voivodeship varies. Next to each other, there function the groups of Euro-enthusiasts and Euro-skeptics. The former ones used the possibilities that the membership in the Union offers. They tried to modernize their households, often with the use of EU funds. They developed the majority of uncultivated land and attempted to increase the total acreage of a household. What is more, they also declare to introduce such changes also in the future. What characterizes Euro-enthusiasts is larger marketability of production and higher income obtained from the sale of agricultural produce. The respondents perceiving positively the condition of Polish agriculture, as a rule, assessed more positively the situation in their own agricultural household. Euro-skeptics showed far less initiative and willingness to improve the economic condition of their households. Those were mainly older people and the users of small agricultural households.

However, for most farmers, the accession of Poland to the EU is not connected with any changes concerning the functioning of their own agricultural households. They remained passive to the ongoing political and economic transformations influencing the condition of their own agricultural households. What seems optimistic is the fact that in comparison to 2003 , 
when the pre-accession referendum was held, the number of the EU-entry supporters among its former opponents grew. Nevertheless, the support for the EU among the farmers is generally on a downward trend. The farmers often feel cheated by the Community as they receive lower subsidies and are exposed to unhealthy competition with the farmers of the "old" Union. What is more, the benefits connected with the opening of the market towards the West do not compensate for the losses of large markets in the countries of the Commonwealth of Independent States.

\section{References}

[1] BAŃSKI J. (2004): Wybrane problemy rozwoju gospodarstw rolnych w opinii ich właścicieli wyniki badań ankietowych. In: Parysek. (ed.): Rozwój regionalny i lokalny w Polsce w latach 1989-2002 (pp. 247-261). Poznań: UAM, Bogucki Wyd. Naukowe.

[2] BAŃSKI J., CZAPIEWSKI K. (2003): Referendum na wsi a opinie na temat UE - wybrane wyniki badań ankietowych. In: Kowalski M. (ed.): Przestrzeń wyborcza Polski (pp. 73-85). Warszawa: IGiPZ PAN, PTG.

[3] BAŃSKI J., STOLA W. (2002): Przemiany struktury przestrzennej i funkcjonalnej obszarów wiejskich w Polsce. Studia obszarów wiejskich 3. Warszawa: PTG, IGiPZ PAN.

[4] KULIKOWSKI R. (2005), Działalność i źródła dochodu indywidualnych gospodarstw rolnych w Polsce - aspekty przestrzenne. Przegląd Geograficzny 77(4), 527-550.

[5] MANGIONE T. (1999): Ankietowanie pocztowe $w$ badaniach marketingowych i socjologicznych. Warszawa: Wydawnictwo Naukowe PWN.

[6] Zarząd województwa lubelskiego. (2005). Strategia rozwoju województwa lubelskiego na lata 2006-2020 (2005). Lublin. 